\title{
BREXIT, AVOIN JULKAISEMINEN JA AVOIN TIEDE
}

Näyttää siltä, että Britannia lähtee Euroopan unionista 29.3.2019, joko sopimuksella tai ilman. Brittilehdistön mukaan yritykset muuttavat tai harkitsevat muuttoa Manner-Eurooppaan. Punnan arvo laskee laskemistaan ja britit hankkivat euroja. EU:n alueelle asettuneet britit ja muualta Eu:sta Britanniaan muuttaneet ovat huolissaan tulevaisuudestaan.

Entä miten Britannian ero Euroopan unionista vaikuttaa kirjastoihin ja avoimeen tieteeseen?

Yliopistoissa ja korkeakouluissa pelätään, että EU-rahoitus loppuu ja ulkomaalaisten opiskelijoiden ja henkilökunnan tilanne vaikeutuu. Kun punnan arvo laskee, tutkimuslaitosten ja kirjastojen on yhä vaikeampaa maksaa alati kallistuvia aineistojen tilausmaksuja, jotka maksetaan usein dollareissa ja euroissa. Kansainvälinen yhteistyö tutkimuksessa ja kirjastotyössä muuttuu, kun ei olla enää Eu:ssa.

Brexitin nähdään tarjoavan uhkien lisäksi myös mahdollisuuksia. Britannia on jo tähän mennessä saanut paljon aikaan avoimen julkaisemisen saralla itsenäisesti, ilman muuta Eurooppaa. Avoimessa julkaisemisessa Britannia tulee etenemään joka tapauksessa. EU:n sääntelystä vapautuminen voi myös tuoda vapautta tutkimuksen tekoon.

Uhat ovat kuitenkin todellisia. Miten Britannia suhtautuu Eu:n tekijänoikeusuudistukseen, joka käsittelee muun muassa tekstin ja datan louhintaa? University College Londonin kirjastopalveluiden johtaja ja Liberin entinen presidentti Paul Ayris näkee, että Britannian tulee yrittää saada samantapaiset säännöt ja sopimukset kuin Euroopan unionilla on, jo senkin vuoksi, ettei yhteistyö Eu-maiden yliopistojen kanssa vaikeutuisi.

Ayris muistuttaa, että Britannia ei eroa Euroopasta, vaan vain Euroopan unionista. Yhteistyön on jatkuttava, Britannia ei saa jäädä yksin. Britannian tulee olla osa avoimen tieteen European Open Science Cloud -tutkimuspalvelualustahanketta.

Moni näkee, että valeuutisten aikakautena kirjastojen ja kirjastotyöntekijöiden rooli on keskeisen tärkeä. Heti Brexit-äänestyksen jälkeen, kesäkuussa 20I6, Oxfordin yliopiston Bodleian-kirjaston johtaja Richard Ovendon kirjoitti näin:

Olemme selvinneet Euroopan konflikteista, rutoista ja nälänhädistä, monenlaisista talouskriiseistä viimeisen 400 vuoden ajan, enkä epäile lainkaan, ettemmekö olisi riittävän vahvoja kestääksemme edessä oleva myrskyt. Arvojemme keskiössä on ajatus sitä, että olemme kansainvälinen instituutio, ja olemme olleet sitä perustamisestamme lähtien. Tulemme toivottamaan tervetulleeksi lukijat Euroopasta ja munalta maailmasta. Tulemme hankkimaan kokoelmia Euroopasta ja munalta maailmasta. Meillä tulee jatkossakin olemaan kansainvälistä henkilökuntaa ja arvostamme heidän panostaan yhteisössämme. (...) Me jatkamme 
CERLissä, LIBERissä ja muissa yhteistyöhankkeissa Euroopassa. (...) Kansainvälisenä instituutiona meidän tulee kaksinkertaistaa yrityksemme toivottaa tervetulleeksi ja olla suvaitsevaisia, olla uskollisia periaatteellemme palvella "oppineiden tasavallan" jäseniä, mistä tahansa he tulevatkin. (Ovendon 2016, suomennos kirjoittajan.)

S. R. Ranganathanin viidettä lakia mukaillen David McMenemy näkee sekä kirjastot että kirjastonhoitajat muuttuvina organismeina. Sitä on tietysti myös EU. Ne elävät ja muuttuvat ajan mukana. Kirjastoalan arvot ovat kuitenkin varsin pysyviä. Kirjastoille ja kirjastojen työntekijöille yhteistyö, kansallinen ja kansainvälinen, on aina ollut luontaista. Aineistojen saatavuus - kaukolainoista avoimeen tieteeseen - on aina ollut meille olennaisen tärkeää. Se ylittää rajat, myös EU:n rajat.

Johanna Lahikainen

\section{Lähteet:}

Ayris, Paul, 20 18: Brexit - and its potential impact for Open Access in the UK. http://dx.doi.org/I0.14324/ooo.learn.04 (Luettu I7.2.2019.)

British Library Board, 2017: Implications for Brexit for The British Library. http://www.bl.uk/aboutus/foi/pubsch/pubscheme4/BLB\%201747.pdf

(Luettu 17.2.2019.)

Inman, Phillip, Helm, Toby, Boffey, Daniel and Savage, Michael, 20 i9: uk firms plan mass exodus if May allows no-deal Brexit. The Guardian 26.I.2019. https:/www.theguardian.com/politics/2019/jan/26/brexit-british-firms-mass-exodusno-deal (Luettu I7.2.2019.)

McMenemy, David, 2007: Ranganathan's relevance in the 21st century. Library Review, Vol. 56 Issue: 2, pp. 97-IOI, https://doi.org/IO.I I08/00242530710730268

Morris, Laurence, 20i6: The implications of Brexit for libraries: an Academic Librarian's perspective. https://www.e-ir.info/2016/ I 2/23/the-implications-ofbrexit-for-libraries-an-academic-librarians-perspective/ (Luettu 17.2.2019.)

Ovendon, Richard, 2016: Bodley's Librarian's response to eu Referendum. 24.6.20 I6. https://www.bodleian.ox.ac.uk/bodley/about-us/librarian/eu-ref (Luettu 17.2.2019.)

Wyatt, Tim, 20 I9: Britons stockpiling euros as Brexit day draws nearer. The Independent 17.2.2019. https:/www.independent.co.uk/news/uk/home-news/ euros-pounds-sterling-currency-brexit-no-deal-29-march-a878359r.html

(Luettu 17.2.2019.) 